\title{
New Infrastructure and Corporate Value Creation: Theory and Practice in China
}

\author{
Zhixin $\mathrm{XUE}^{*}$ and Xiaojing CHAO \\ 1 School of Economics \& Management, Research Institute of Economy and Development of Western China, \\ Northwest University, Xi'an, China; xuezhixin0106@163.com \\ * Corresponding author: xuezhixin0106@163.com
}

\begin{abstract}
During the post-epidemic era, solving the problem of new infrastructure has become an urgent need to realize the value growth of Chinese companies. However, whether the process of new infrastructure will have a positive effect on China's corporate value has become a key issue that needs to be answered urgently. Based on the panel data of China's listed companies from 2010 to 2018, this paper makes an empirical study on the relationship between new infrastructure and corporate value of China's listed companies. The results of mean regression show that the strengthening of new infrastructure has a significant positive impact on the corporate value. In addition, technology intensive industries, private enterprises and growing enterprises have significant positive adjustment on the relationship between the new infrastructure and corporate value. Among them, the growth of enterprises has the greatest influence on them. Therefore, China should further strengthen the construction of new infrastructure to ensure its driving in the process of improving the company's value creation.
\end{abstract}

Keywords: new infrastructure; corporate value; adjustment effect; micro-enterprise behavior

JEL Classification: L2; O3; M2

\section{Introduction}

Industrial system and trade rules are facing severe challenges in the period of structural adjustment of China's economic development. If China wants to build a modernized socialist country, it must seize the new opportunities brought by the new round of scientific and technological revolution and industrial reform, and strive to achieve higher quality development. The core of high-quality economic development at the micro level lies in the promotion of enterprise value, and enterprise digital transformation is the key to the promotion of enterprise value. As a typical performance of enterprise digital transformation, new infrastructure pays more attention to the digital reconstruction of new technology, new mode and new format than traditional infrastructure. Therefore, will the new infrastructure replace the traditional infrastructure and have an impact on the company's value? How to promote enterprises to form a higher level of dynamic balance?

The existing literature mostly studies the corporate value from the micro and meso perspectives of EVA assessment, management incentive, political connection, family management relationship, corporate social responsibility, and industrial globalization (Chi 
et al., 2013; Li et al., 2016; Zhan \& Wang, 2013; Chen et al., 2017; Wang \& Xu, 2016). However, there are few studies on the impact of infrastructure on corporate value at the macro level, mainly focusing on the impact of transportation infrastructure on enterprise inventory and resource allocation efficiency (Zhang et al., 2017; Li \& Tang, 2014), Or the research on the effect of information infrastructure on export performance (Li et al., 2015), which pay less attention to the impact of new infrastructure on corporate value.

The new infrastructure is an infrastructure system formed by the evolution, integration and overlapping iteration of new generation information technologies such as 5G, Internet, industrial Internet, artificial intelligence, cloud computing and data center $(\mathrm{Xu}, 2020)$. It can not only expand the scope of data collected by enterprises, promote enterprises to extract data from heterogeneous resources more conveniently and smoothly, form the data scale effect, promote the enterprise value, but also enhance the collaboration among various departments and upstream and downstream enterprises through collaborative management in order to achieve self-strengthening and enhance enterprise value. Based on the above carding, this article believes that new infrastructure can promote the value of Chinese enterprises.

\section{Methodology}

The sample interval of this article is from 2010 to 2018, the data used are the operating data of Chinese listed companies in China. The data used in the above data are all from DRCNET Statistical database and CSMAR Service Center. Due to the lack of data in Tibet, Hong Kong, Macau, Taiwan provinces, and St \& TT companies are excluded. While linear interpolation was used to supplement a small number of missing values, in order to avoid the influence of outliers on the regression results, a $1 \%$ bilateral tailing process was performed on all continuous variables.

Among them, referring to the practices of Liu and Zhang (2016) and Wu (2019), this article chooses to take Tobin $Q$ value as the measure of the company value(ev). When measuring new infrastructure, this paper measures the new infrastructure of cities(di) in the following ways: Firstly, determine the new infrastructure related vocabulary. This paper holds that the word frequency reflecting the new infrastructure includes 5G, mobile communication and information technology and so on. Secondly, manually collect the government work reports of 30 provinces and autonomous regions from 2010 to 2018, and segment the government work reports; Thirdly, the frequency proportion of words related to the new infrastructure is counted. Finally, selects the allocation efficiency of prefecture level cities to multiply with the new infrastructure, and obtains the new infrastructure data at the prefecture level.

In addition, the following control variables are selected in this article: (1) Operating cost ratio(ocr) is defined as the proportion of operating cost and operating income; (2) Employee compensation payable(wage) is measured by the logarithm of per capita employee compensation payable of listed companies; (3) Enterprise age(age) is defined as the number of years from the listing to the research year; (4) Equity concentration (shr) is measured by the shareholding ratio of the top ten shareholders; (5) $R \& D$ investment level (rea) is 
measured by the proportion of R\&D investment in operating revenue; (6) Enterprise scale (ass) is expressed as the total assets of the company after taking the natural logarithm.

Table1. Descriptive statistics of variables

\begin{tabular}{|c|c|c|c|c|c|}
\hline Variable & Mean & St.d & Min & Max & N \\
\hline ev & 2.680949 & 1.94935 & 0.882626 & 11.90137 & 21,812 \\
\hline di & 0.992293 & 1.026456 & 0 & 4.522082 & 22,791 \\
\hline ocr & 0.7092179 & 0.174932 & 0.1736312 & 1.004333 & 22,784 \\
\hline wage & 16.87911 & 1.664381 & 11.9073 & 21.2893 & 22,625 \\
\hline age & 20.80849 & 5.193178 & 11 & 34 & 19,383 \\
\hline shr & 59.56264 & 15.80558 & 22.41 & 94.61 & 22,773 \\
\hline rea & 4.496068 & 4.345019 & 0.03 & 25.62 & 16,360 \\
\hline ass & 22.03087 & 1.301655 & 19.47466 & 26.0246 & 22,791 \\
\hline
\end{tabular}

In order to further understand the correlation between new infrastructure and corporate value, this paper makes a univariate analysis. It can be seen from the results in Table 2 that the average value of the group with high new infrastructure is higher, and they are all significant at the $1 \%$ level, which provides preliminary evidence that the increase of new infrastructure investment helps to enhance the value of the company.

Table 2. Mean test of new infrastructure and company value

\begin{tabular}{|c|c|c|c|c|c|}
\hline \multirow{2}{*}{} & Category & \multirow{2}{*}{$\mathbf{N}$} & \multicolumn{3}{|c|}{ Corporate value } \\
\cline { 4 - 5 } & & Mean & Diff & T test \\
\hline \multirow{2}{*}{ di } & high & 8,220 & 2.943787 & \multirow{2}{*}{0.4070491} & \multirow{2}{*}{$14.8856^{* * *}$} \\
\cline { 2 - 4 } & low & 13,625 & 2.536738 & & \\
\hline
\end{tabular}

\section{Results}

\subsection{Construction of the Economic Model}

Based on the above theoretical analysis ideas, in order to capture the actual impact of new infrastructure on corporate value, this article builds the following basic measurement models:

$$
e v_{i t}=\alpha_{0}+\alpha_{1} d_{i j t}+\beta X_{i t}+v_{j}+v_{r}+\varepsilon_{i t}
$$

Among them, the explained variable is $e v_{i t}$, which represents the corporate value; $\mathrm{i}$ and $\mathrm{t}$ represent the enterprise and year respectively, and the core explanatory variable is dit, which represents the degree of new infrastructure. $X_{i t}$ is a series of factors that affect the value of a company, including: operating cost ratio (ocr), employee compensation payable (wage), enterprise age(age), equity concentration (shr), R\&D investment level (rea) and enterprise scale(ass). $v_{j}, v_{r}$ are industry, regional dummy variables, respectively, reflecting industry fixed effects, regional fixed effects. $\varepsilon_{i t}$ is a random perturbation term. 


\subsection{Results of the Benchmark Model}

In the benchmark regression section, the fixed effect model is used to estimate the role new infrastructure level of Chinese prefecture-level cities in 2010-2018 on the corporate value of local listed companies. Table 3 is the corresponding benchmark regression results. In column (1), the coefficient of $D I$ is significantly positive and significant at the $1 \%$ confidence level, which indicates that the company value will increase significantly with each additional unit of new infrastructure. In column (2), the estimated coefficient of new infrastructure is significantly positive at the level of $1 \%$, which is consistent with the results in column 1 . In column (3), the new infrastructure coefficient is 0.514 , and the direction does not change significantly, which is still significant at the level of $1 \%$. It shows that the construction of new infrastructure can significantly enhance the company value.

Table 3. Impact of new infrastructure on company value

\begin{tabular}{|c|c|c|c|}
\hline & \multicolumn{3}{|c|}{ Corporate value } \\
\hline & $(\mathbf{1})$ & $(\mathbf{2})$ & $(3)$ \\
\hline $\mathrm{di}$ & $0.350^{* * *}$ & $0.508^{* * *}$ & $0.514^{* * *}$ \\
\hline & $(0.0185)$ & $(0.0217)$ & $(0.0218)$ \\
\hline control & YES & YES & YES \\
\hline cons & $18.73^{* * *}$ & $18.50^{* * *}$ & $18.98^{* * *}$ \\
\hline & $(0.501)$ & $(0.442)$ & $(0.503)$ \\
\hline $\mathrm{Vj}$ & YES & NO & YES \\
\hline $\mathrm{Vr}$ & NO & YES & 12,600 \\
\hline $\mathrm{N}$ & 12,600 & 12,603 & 0.398 \\
\hline $\mathrm{R} 2$ & 0.382 & 0.373 & 322.4 \\
\hline $\mathrm{F}$ & 303.1 & 408.3 & \\
\hline
\end{tabular}

\subsection{Results of the Heterogeneity Test}

The above basic econometric model mainly describes the positive promotion effect of new infrastructure on the company value in the mean range, ignoring their heterogeneity. Firstly, the impact of new infrastructure on the value of Companies in different industries may be different. Compared with non-technology-intensive industries, technology-intensive industries need more knowledge and information, and new infrastructure plays a more important role in promoting the value of technology intensive companies. Therefore, referring to the division basis of technology intensive industries by Lv et al. (2020), this paper divides all enterprises into two groups for technology-intensive industry and non-technology-intensive industry for empirical test. It can be seen from the results in the first two columns of Table 4 that when the new infrastructure increases by one unit, the company value of technology intensive industries will increase by 0.514 units, while that of non-technology intensive industries will increase by 0.496 units, which indicates that the new infrastructure has a greater promoting effect on the company value of technology intensive industries than that of non-technology intensive industries.

Secondly, compared with private enterprises, state-owned enterprises have problems in top-level design, technology integration and data management and control, which affect the promotion of new infrastructure to corporate value. Therefore, according to the nature of 
equity, this paper divides all enterprises into state-owned enterprises and non-state-owned enterprises for empirical test. Columns (3) and (4) of Table 4 report the regression results of the impact of new infrastructure construction on corporate value under different ownership nature. The results show that new infrastructure construction can enhance the value of both types of ownership companies, and the promotion effect of new infrastructure construction on the value of non-state-owned companies is much higher than that on the value of state-owned companies.

Finally, for the division of different growth stages of enterprises, this paper divides the enterprises whose age is lower than the average age of the whole sample enterprises into growing enterprises, and the rest are mature enterprises. The regression results are shown in the last two columns of Table 4. It can be seen that the new infrastructure has a significant role in promoting the value of both growth and mature companies. However, as far as the regression coefficient is concerned, the regression coefficient of the new infrastructure of the growing enterprises is 1.39 times that of the mature enterprises, which means that the new infrastructure has a strong promotion effect on the growing enterprises. This may be due to the fact that growing enterprises need digitalization more. For example, the 2020 digital initialization index of small enterprises in China released by Dell IDC points out that more than $50 \%$ of small enterprises attach importance to digitalization, and most growing enterprises pay more attention to subdivision fields, with rapid growth and huge development potential. Therefore, new infrastructure as an important means to promote digital transformation, the higher the level of new infrastructure construction, the more conducive to the growth of enterprises to enhance their corporate value.

Table 4. Heterogeneity test of new infrastructure on corporate value

\begin{tabular}{|c|c|c|c|c|c|c|}
\hline \multirow{3}{*}{ Estimation } & \multicolumn{6}{|c|}{ Corporate value } \\
\hline & \multicolumn{2}{|c|}{ Industry heterogeneity } & \multicolumn{2}{|c|}{ Firm nature heterogeneity } & \multicolumn{2}{|c|}{ Firm age heterogeneity } \\
\hline & $\begin{array}{l}\text { Technology- } \\
\text { intensive ind } \\
\text { ustries }\end{array}$ & $\begin{array}{c}\text { Non } \\
\text { technology-i } \\
\text { ntensive ind } \\
\text { ustries } \\
\end{array}$ & $\begin{array}{c}\text { State-owned } \\
\text { enterprise }\end{array}$ & $\begin{array}{c}\text { Non } \\
\text { state-owned } \\
\text { enterprise }\end{array}$ & $\begin{array}{c}\text { Mature } \\
\text { enterprise }\end{array}$ & $\begin{array}{c}\text { Growth } \\
\text { enterprise }\end{array}$ \\
\hline \multirow[t]{2}{*}{ di } & $0.514^{* * *}$ & $0.496^{* * *}$ & $0.273^{* * *}$ & $0.619^{* * *}$ & $0.412^{* * *}$ & $0.574^{* * *}$ \\
\hline & $(0.0218)$ & $(0.0258)$ & $(0.0286)$ & $(0.0283)$ & $(0.0302)$ & $(0.0301)$ \\
\hline Control & YES & YES & YES & YES & YES & YES \\
\hline \multirow[t]{2}{*}{ _cons } & $18.98^{* * *}$ & $18.03^{* * *}$ & $16.18^{* * *}$ & $21.24^{* * *}$ & $18.57^{* * *}$ & $19.39^{* * *}$ \\
\hline & $(0.503)$ & $(0.580)$ & $(0.772)$ & $(0.745)$ & $(0.840)$ & $(0.671)$ \\
\hline $\mathrm{Vj}$ & YES & YES & YES & YES & YES & YES \\
\hline $\mathrm{Vr}$ & YES & YES & YES & YES & YES & YES \\
\hline $\mathrm{N}$ & 12,600 & 7,946 & 3,784 & 8,814 & 5,183 & 7,414 \\
\hline $\mathrm{R} 2$ & 0.398 & 0.420 & 0.454 & 0.355 & 0.421 & 0.392 \\
\hline $\mathrm{F}$ & 322.4 & 197.8 & 64.79 & 224.0 & 120.1 & 190.8 \\
\hline
\end{tabular}

\section{Discussion}

In order to answer the key question whether new infrastructure can promote corporate value, this paper uses mean regression as experiments to test new infrastructure can promote corporate value. Compared with the existing research literature, this article mainly 
expands the existing research from the following aspects: Firstly, enriching and expanding the theoretical research on the value of new infrastructure to the company. In addition, there is a significant difference between the new technology and the traditional infrastructure in the nature of the new infrastructure. Secondly, based on the panel data of China's A-share listed companies from 2010 to 2018, this paper systematically studies the driving effect of new infrastructure on corporate value. Few researches empirically test the impact of new infrastructure on corporate value from the perspective of macro level. This paper finds that the new infrastructure has obvious driving effect on corporate value. Finally, this paper tests the difference of the driving effect of new infrastructure on the company's value, which provides targeted decision-making basis for the formulation of new infrastructure related policies.

\section{Conclusions}

The driving characteristics of new infrastructure to China's economic development are continuously emerging. This paper investigates the theoretical mechanism of new infrastructure to company value based on the micro level, and analyzes the promotion effect and mechanism of new infrastructure to company value based on the panel data of China's listed companies from 2010 to 2018. The results show that: on the one hand, the new infrastructure significantly drives the company's value, so the new infrastructure construction is a new driving force for enterprises to obtain sustainable competitive advantage. On the other hand, new infrastructure plays a greater role in promoting the value of technology intensive industries, private enterprises and growing enterprises. Therefore, China should further strengthen the construction of new infrastructure. Focus on the segmentation of new infrastructure, strengthen the deployment of industrial Internet,5G, data center, give full play to the scale effect and cluster effect of new infrastructure, and lead enterprises to realize value creation. At the same time, improve the efficiency of enterprise resource allocation. In the process of new infrastructure construction, Chinese enterprises need to fully consider their own situation and regional data level, and improve the construction of new infrastructure in non-technology-intensive industries, state-owned enterprises and mature enterprises, so as to realize the rational allocation of data resources more effectively.

Acknowledgments: This work was supported by Shaanxi Social Science Fund (Grant No 2019D018), Research on High Quality Development Strategy of Yellow River Basin, Special Support Plan for High-level Talents in Shaanxi Province and Support for Outstanding Young Talents in Shaanxi Province.

\section{References}

Banerjee, A, Duflo, E., \& Qian, N. (2020). On the road: Access to transportation infrastructure and economic growth in China. Journal of Development Economics, 145. https://doi.org/10.1016/j.jdeveco.2020.102442

Chen, A. (2017). Big data and the development of regional economy. In 2016 International Conference on Modern Management (pp. 177-181). Advances in Social Science, Education and Humanities Research. https://doi.org/10.2991/mmetss-16.2017.32

Chen, Z., Wu, M., \& Chen, Z. (2017). The path of family management affecting the value of small and medium-sized family companies: a study of agency theory and efficiency theory based on industry competition. China Industrial Economy, 5, 113-132. https://doi.org/10.19581/j.cnki.ciejournal.2017.05.008 
Chi, G., Wang, Z. \& Yang, J. (2013). Does EVA improve company value? - Empirical evidence from Chinese state-owned listed companies. Accounting Research, 11, 60-66.

Liu, X., \& Zhang, C. (2016). Corporate governance, social responsibility information disclosure, and enterprise value in China. Journal of Cleaner Production, 142, 1075-1084. https://doi.org/10.1016/j.jclepro.2016.09.102

Li, H., \& Tang, L. (2015). Transportation infrastructure investment, spatial spillover effect and enterprise inventory. Management World, 4, 126-136. https://doi.org/10.19744/j.cnki.11-1235/f.2015.04.012

Li, H., Fu, S., \& Gao, P. (2016). Media attention, carbon information disclosure and corporate value. Statistical Research, 9, 63-69.

Li, K., Shao, W., \& Wang, Y. (2015). Information density, information infrastructure and enterprise export performance: theoretical and empirical analysis based on enterprise heterogeneity. Management World, 4, 52-65. https://doi.org/10.19744/j.cnki.11-1235/f.2015.04.012

Li, X. (2016). Research on corporate value management system based on EVA. Management World, 8, 182-183. https://doi.org/10.19744/j.cnki.11-1235/f.2015.04.012

Lv, Y., Gu, W., \& Bao, Q. (2020). Artificial intelligence and Chinese enterprises' participation in global value chain division. China Industrial Economy, 5, 80-98. https://doi.org/10.19581/j.cnki.ciejournal.2017.05.008

Wang, Q., \& Xu, X. (2016). Value creation mechanism and empirical test of corporate social responsibility -- Based on stakeholder theory and life cycle theory. China Soft Science, 2, 179-192.

Wu, G. (2019). Separation of ownership and corporate value: support Effect or tunneling effect. Journal of Central University of Finance and Economics, 9, 97-106.

Xu, X., Zhang Z., \& Guan, H. (2020). China's new economy: role, characteristics and challenges. Finance and Trade Economy, 1, 5-20.

Zhan, L., \& Wang, Y. (2013). Management incentive, over investment and corporate value. Nankai Management Review, 3, 36-46.

Zhang, T., Gao, X., Bu, X., \& Xie, X. (2017). Does China's transportation infrastructure construction improve the efficiency of enterprise resource allocation? - based on the analysis of highway construction and factor input of manufacturing enterprises. Financial Research, 8, 122-134. 